\title{
Bjørn Bandlien
}

\section{Trading with Muslims and the Sámi in Medieval Norway}

In the Middle Ages, it felt to Norwegians like they were surrounded by heathens. Although they were geographically far removed from the Holy Land, many Norwegians encountered Muslims during pilgrimages and when participating in Crusades. ${ }^{1}$ Moreover, they maintained close contact with the northern heathen 'Finns' or 'Lapps', today usually identified as the Sámi. ${ }^{2}$ In fact, the Norwegian Archbishops of Nidaros went so far as to declare themselves and their patron saint, Olaf, to be the bulwark against the threat from the North, the homeland of demonic forces that threatened to overrun Christendom. ${ }^{3}$

From a modern perspective, there are many obvious differences between the Sámi at the northern fringe of Europe and the Mediterranean Muslims in the Middle Ages. For example, the Mamluks in Egypt had a complex political structure, significant military resources, and were involved in large-scale international trade, while the Sámi were hunters who lived in a society without cities and certainly had no military structure that would pose a serious threat to any kingdom.

Nonetheless, the Sámi were included in Western pro-Crusade discourse alongside the Muslims. King Hákon Hákonsson of Norway (1217-1263) had taken the Cross in 1237, but in 1241, he sent a petition to Pope Gregory IX, asking to be absolved from his vow to participate in a Crusade to the Holy Land. He listed a number of difficulties, including a lack of necessary economic resources. He promised, instead, to make war on his kingdom's heathen neighbours. Pope Gregory IX responded by granting the king a part in the Crusading indul-

1 The standard work remains Riant 1865.

2 In this article, I will use medieval terms, such as Finnar or Saracens, when discussing images of groups designated as such in medieval sources, and modern terms, such as Sámi, Arabs and Muslims when referring to historical groups and individuals. The relationship between medieval and modern terms is of course more complicated. For instance, it is not certain that the Old Norse term Finnar covered the modern 'Sámi' or if the distinction between Bjarmar and Finnar was very clear to medieval Norwegians. Furthermore, Finnar sometimes appears even as synonymous with 'trolls'. It is difficult to ascertain the indigenous terminology used in the Middle Ages by those we today would call 'Sámi'; see the discussion in Hansen and Olsen 2014, 35-38. Saracens could be a term for many types of heathens: for instance in Middle English romances it even included heathens from Scandinavia.

3 For a discussion of this theme, see Skånland 1956. 
gence and sending a letter extending papal protection to the king, his family, and his property. ${ }^{4}$

A similar excuse was offered in response to the call for a Crusade at the Council of Vienne in 1311-1312. When papal collectors arrived in Norway to claim Crusading tithes, the head of the royal council and de facto ruler of Norway in the 1320s, Erling Vidkunsson, claimed to be planning his own Crusade against Norway's heathen neighbours. In 1323, he received a letter from Pope John XXII granting the Norwegians who died fighting the pagani dicti Finnar (heathens called Finnar) the same privileges as those who died fighting for the liberation of the Holy Land. ${ }^{5}$ In 1326, John XXII also granted the young King Magnus Eriksson's guardians a portion of the Crusading tithes to finance the war against the heathen Karelians and the heretical Russians. ${ }^{6}$

This suggests that Norwegian rulers in the thirteenth and fourteenth centuries viewed their relations with the heathens at their borders as part of the same struggle for Christendom as that against the Saracens in the Middle East, against the Moors in Spain, and against the heathens in the Baltic region. Norway's heathen neighbours were located at the kingdom's northern border. Along with the Sámi, other groups with interests in northern Scandinavia were identified as heathens, among them the Bjarmar and the Karelians, as well as the Russians (the latter were sometimes referred to as heathens and sometimes as heretics).

Stereotyping both the Sámi and Muslims as equivalent Others is in line with the general development of a 'persecuting society' in the High Middle Ages. In his influential study of medieval European persecuting society, Robert I. Moore argued that the images used to identify marginal groups, such as Jews, lepers, and heretics, as well as the way in which they were persecuted, were very similar. The development of a new bureaucracy and a new rhetoric of authority, morality, and normalcy contributed to this. ${ }^{7}$ Norwegians and other European Christians shared a common image of Muslims, and by the early fourteenth century at the latest, heretics were targeted for persecution. ${ }^{8}$ In medieval Norway, the negative stereotypes of the Muslims led to the construction

\footnotetext{
4 DN I, 1849, 24; see also Jackson 2009, 23. Gregory IX had in 1237 promised full absolution and papal protection to those who participated in a campaign against heathens who attacked the recently converted Tavastians in southern Finland, DS 298/SDHK 514.

5 DN VI, 1864, 106.

6 DN VI, 1864, 113.

7 Moore 2007.

8 On the persecution of heretics and the scattered references to inquisitors in Norway, see Bandlien and Knutsen 2008.
} 
of the Saracens, or Serkir in Old Norse, with their well-established polytheistic faith, idol worship, and cruelty. ${ }^{9}$ Historian Sirpa Aalto has argued that the negative, or even monstrous, qualities assigned to heathen enemies can be traced to patterns found in the Old Norse kings' sagas. The heretical and heathen groups who were assigned traits similar to other 'non-Christians' included, among others, the Karelians, Bjarmar, Wends, blámenn (conventionally translated as 'black men'), and Sámi in the north. For example, in the Icelandic sagas, the Sámi were often portrayed, in a corresponding way, as skilled in magic or demonic sorcery and as heathen idol worshippers. ${ }^{10}$ This suggests that the traits assigned where influenced by images of the Other that the Norwegians shared with other Europeans. ${ }^{11}$

However, as was the case for other Europeans, Norwegians had relations with the Sámi and Muslims that were more complex than allowed for in the depictions of the Saracens and Finnar in sagas, chansons de geste, chronicles, and romances. ${ }^{12}$ Although the Sámi and Muslims were depicted as enemies of Christianity, sagas and chronicles testify that Norwegians continued to trade with them. While representations of these groups as monstrous Others would contribute to a Christian identity and community, trading relations and peaceful contact would seem to endanger such simple oppositions. However, as Emile Durkheim pointed out a century ago, trade may provide little more than a fragile peace: "Interests never unite men but for a few moments, contracts are mere truces in a continuing antagonism. Nothing is less constant than interest. Today it unites me to you; tomorrow, it will make me your enemy". ${ }^{13}$ In the case of medieval Iberia, the view is that face-to-face trade relations lent stability to the Muslim-Christian convivencia. ${ }^{14}$ David Nirenberg, in his study on the relations between Christians and Jews, Muslims, and lepers in France and in the Crown of Aragón, counters the view held by Robert I. Moore, Norman Cohn, and others, arguing that the role and objective of stereotypes of the Other "are closely dependent on social context and conflict, and therefore differ greatly from time to time and place to place". ${ }^{15}$ According to Nirenberg, persecution of and violence against minorities was short-lived and was generally determined by the way in which the perpetrators took hold of and manipu-

9 Sverrir Jakobsson 2012.

10 Mundal 1996; Hermann Pálsson 1997.

11 Aalto 2010.

12 Sverrir Jakobsson 2012; Bandlien, forthcoming.

13 Durkheim 1964, 203-204.

14 Meyerson 2003.

15 Nirenberg 1996, 124. 
lated the discourse about the Other. Furthermore, episodes of aggression against minorities were not always socially disruptive: They often played an integrative and stabilizing role, clarifying ethnic, religious, and social boundaries and making different group identities more tangible.

In this paper, I will examine the interrelationship of trading, religious missions, and Crusading based mainly on Scandinavian sagas and chronicles. In these narratives, trading relations with heathens are most often recorded because of their noteworthiness to an élite audience of clerics, monks and nobles, many of them connected to the Norwegian royal court. Given the lack of archival sources until the Late Middle Ages in Norway, such narratives are especially valuable since they show that boundaries between the Christian and heathen communities could be challenged and upheld during "the few moments" of trade.

\subsection{Trading and Crusading}

At the Second Council of Lyon in 1274, Pope Gregory X excommunicated and anathematized those "false and impious Christians who [...] transport weapons and iron and wood [to the Saracens] for building galleys and other sailing vessels with which they [the Saracens] attack Christians [...] or in anything else whatsoever lend them aid or counsel to the detriment of Christians, particularly those of the Holy Land". ${ }^{16}$ Jon Raude, Archbishop of Nidaros in Norway, attended the Council in Lyon, and in 1280 he included the same embargo in a provincial statute, under threat of excommunication. ${ }^{17}$

Attempts at an effective commercial boycott of the Muslims had begun in the twelfth century. The Third Lateran Council, under Pope Alexander III, provided the first clear formulation of the principle. As had been the case at the Second Council of Lyon, the export of weapons, slaves, and shipbuilding materials to Muslims was considered a particularly serious offense. Occasionally, there were more extensive embargos: The Fourth Lateran Council of 1215 forbade Christians to send ships to countries inhabited by the Saracens for a period of four years, because they should remain available to those who wished to act in service of the Holy Land, and so that the "Saracens may be denied the

16 Bird, Peters, and Powell 2013, 470.

17 Keyser et al. 1849, 237: "I ellifta fellr á pa fullkomit bann sem Saracenis flytia til handa vápn eða skip eða iarn, eða geraz skipstiornar menn peirra, eða veita peim nockurs kyns fullting til agángs ok ufriðar heilögu Jorsala landi ok kristnu folki.” 
benefits that they usually reap from such commercial intercourse". ${ }^{18}$ After the fall of Acre in 1291, Pope Nicholas IV tried to extend the embargo on arms, horses, iron, wood, and foodstuffs, to include "any other form of merchandise" - in essence, a complete embargo. ${ }^{19}$

The attempts at regulating commerce with Muslims reflects the flourishing trade conducted by merchants from cities like Venice, Genoa, Marseille, and Pisa across religious borders in the Mediterranean, including the export of war materials to Egypt, Tunis, and Syria. ${ }^{20}$ Although Norwegians did not play a significant role in the trade in war materials, it is nonetheless notable that Lodin Lepp served as Norwegian King Magnus Hákonsson's envoy to Egypt in the 1270s, during Baibars' reign. ${ }^{21}$ Although the Icelandic source does not mention the purpose of the journey, it does say that it made Lodin famous. We know from other sources that he had also been sent by the Norwegian king to al-Mustansir in Tunis in 1262. It is possible that Lodin Lepp and other Norwegians met ambassadors from al-Mustansir already during a stay in Valladolid in 1258.22 Lodin was well received by al-Mustansir in 1262 and stayed in Tunis over the winter. Sturla Pórðarson, nephew of Snorri Sturluson, who probably knew Lodin Lepp personally, mentions that the Norwegians brought many gifts with them, including gerfalcons "and other things that were difficult to find there”. These were not, however, merely gifts: They would also have been meant to send a message, given that gerfalcons were a very valuable commodity in the Maghreb, Egypt, and Syria. The contemporary Muslim author Ibn Sa'ìd al-Maghribī wrote that these falcons were so highly valued that even dead specimens sold for a very high price. ${ }^{23}$ Such a gift might, therefore, have been given to Baibars, the Mamluk sultan of Egypt, to encourage trade and increase prices.

A more extensive report about Norwegian trade with Muslims is found in Orkneyinga saga, probably composed in several stages around 1200. It provides a lengthy description of the Norwegian magnate Erling Kyrpinga-Ormsson

18 Menache 2012, 243.

19 Menache 2012, 245-246.

20 Jacoby 2001.

21 Árna saga biskups, ch. 57.

22 According to Hákonar saga (ch. 294, 391), they met envoys in Valladolid, "both Christian and heathens".

23 Birkeland 1954, 99-100. Ibn Sa 'īd al-Maghribī was born in Granada in 1213 and probably died in Tunis in 1286. He arrived at Tunis in 1254 or 1255, following many years travelling and an extended stay in Egypt. Although we cannot be certain, he may very well have been in Tunis in 1262-1263. On the history of Tunis in this period, with references to the Valladolid meeting and the Norwegian envoy, see Brunschvig 1940, 39-70 and Messier 1986. 
leading a Crusading fleet to the Holy Land in the early 1150s, in the company of Earl Ragnvald of Orkney. According to Orkneyinga saga, upon entering the Mediterranean, the Crusaders caught sight of a dromund, a ship so large that they initially thought it was an island. As the ship approached, the Crusaders could not help but wonder whether the crew of the dromund were friends or enemies. At this point it is clearly stated: "If those [on the dromund] are heathens, then the Almighty God will show us mercy and give us victory”. The saga then explains that: "On the dromund were Saraceni, who we call Maúmet's heretics". However, the author goes on to distinguish among these Saracens. Black-skinned warriors receive special mention: "There were many blámenn there, and they fought most fiercely". This would imply that others on board were Saracens, but not blámenn, and that they fought less fiercely.

However, the Crusaders also noticed a man whom they thought appeared different: "A man on the dromund was both larger and more striking than the others. The Norwegians assumed he was the chieftain”. The Crusaders cleared the ship, sparing only this singularly striking man. Then, they headed for the mainland and "went to a town of the Serkir and made peace with them for seven days. They traded with them and sold silver and other things to them". The Crusaders also wanted to sell their captive, but "no one wanted to buy the large man”. Finally, they let him go. ${ }^{24}$

A few days later he returned to the town with a great force and informed the terrified Crusaders "that he was a chieftain from Serkland and had sailed with the ship and a crew from this town". Although he had the power to determine the Crusaders fate, the chieftain chose to let them sail on to the Holy Land: "You will now be allowed to leave in peace since you did not kill me and showed me the honour you were able to, considering the circumstances".

This episode gives a complex image of an encounter with the Saracens. First, the saga explains the term Saraceni to the readers, calling them "Maúmets villumenn [the heretics of Maúmet]". The nature of the heresy is not specified, but the contemporary Speech Against the Bishops, written in Norway in the late 1190s, adds more detail. The basic premise of this treatise is that the king should control both the kingdom and the Church, since clerics tended to fall into lechery, pride, greed, lust, and sexual immorality. The list of heretical clerics mentions a certain Nicholas Advena. He is said to be a disciple of Christ, who later became the bishop of Serkland. He then became known by another name, Maúmet. His heretical teaching had spread to such an extent that half

24 Orkneyinga saga, ch. 88, my translation. Orkneyinga saga was probably written in several stages around 1200, but is preserved only in manuscripts from the fourteenth century. 
the world now believed in him and said that he was God. ${ }^{25}$ This image of the Saracens as heretics has been connected to the development of a Christian intellectual culture that responded to the challenge posed by Muslim theology. ${ }^{26}$ However, most of the Saracens were said to be blámenn, a stock image from the Old Norse sagas. They are frequently depicted as the fiercest of warriors, often skilled in magic, and with connections to monstrous beings. ${ }^{27}$

The saga presents the people of Serkland in more neutral terms. No problems are mentioned in relation to the trade in silver and other items with the local merchants. Only when the striking Saracen returns with an army is the religious conflict between the Crusaders and the heathens presented as a potential problem. However, the Saracen proves to be a noble and chivalrous heathen and lets the crusaders leave the city in peace.

This differentiation of Saracens is similar to that found in other European sources. It is well known that trade and commerce followed closely in the wake of Crusades, and that the Genoese in particular used military force to increase their influence in Muslim North Africa. ${ }^{28}$ In the case of the Norwegian and Orcadian expedition in the 1150s, the cities of Bougie (now Béjaiia in the eastern part of modern Algeria) and Tunis were the most likely sites of trade. Genoese merchants had set up in these cities by the mid-twelfth century, although they had rivals among the Christians, particularly the Pisans. ${ }^{29}$

Letters between the Genoese and the local traders suggest close bonds, even during times of internal strife among Christians or between local governors and merchants. ${ }^{30}$ The noble character of the striking heathen chieftain in Orkneyinga saga may have functioned to legitimize trade in Muslim countries. The townspeople, who bought silver and other items from the Crusaders, are also depicted in a similar pronouncedly neutral fashion, simply as the inhabitants of the land of the Saracens, or Serkland. The Norwegian Speculum regale, or Konungs skuggsiá, written at the royal court in the late 1250s, claims that Norwegian merchants often faced danger, both at sea and in heathen lands. ${ }^{31}$ In order to be well received, they were strongly advised to respect local customs wherever they were, including in the land of the Saracens.

The major distinction among the Saracens is the portrayal of the blámenn as fierce warriors. They are also depicted as monstrous and demonic in other

25 En tale mot biskopene 1931, 19.

26 Tolan 2002: 167-168; Bandlien, forthcoming.

27 Aalto 2010; Sverrir Jakobsson 2012.

28 Cheyette 2001, 88-96.

29 Schaube 1906, 275-316.

30 Lopez and Raymond 1955, 384-387.

31 Konungs skuggsiá 1983, 4. 
late twelfth-century sources. Clearly, they were not a group with which it was considered easy to establish peaceful trading relations. The category of Saracens was distinguished as an ethnic Other rather than a religious Other. Orkneyinga saga clearly illustrates how different images of and various perspectives about Muslims could co-exist in a single work.

In 1347, King Magnus Eriksson of Norway and Sweden managed to get papal permission to trade with "Soldan of Babilonia". ${ }^{32}$ King Magnus openly stated that this was necessary to improve the kingdom's economy. To gain permission to trade with the Mamluks in Cairo, the claim was made that it would serve to finance Crusading activities in the East. King Magnus wanted to export falcons, a long and profitable Scandinavian practice. ${ }^{33}$ The falcon trade subsequently received papal exemption from the embargo, and in 1348 Pope Clement VI directed his envoy Peter of Ghent to grant absolution to Scandinavian merchants guilty of illegal trade with Saracens and infidels, if they would use the profits for the war against heathens. ${ }^{34}$ King Magnus assumed that the trading policy of the papacy was considered questionable and was possibly viewed with disapproval. Indeed, two Swedes had in 1345 arrived at an agreement with the merchant Pere de Mediavilla in Barcelona, one of the richest and influential men in the Kingdom of Aragón, to gain passage on his ship to Alexandria. Pere de Mediavilla himself also acted as the King of Aragón's envoy, becoming a very unpopular figure among the French when the claim was made that he had told the Mamluk sultan that the French king was planning to attack Egypt. ${ }^{35}$

While the blámenn were portrayed as monstrous berserkers or demonic idolaters, there seems to have been a parallel interest in narratives that depicted Babylonia more favourably. The cross-cultural contacts in the Mediterranean also influenced the learned and aristocratic worldview in the North, and the Norse aristocrats' aspiration to courtliness may have made admiration for the rich culture they encountered in places like Tunis and Egypt more appealing than simply seeing it as monstrous. ${ }^{36}$

32 DN vII, 1869, 198 and 202. King Magnus also received papal permission to travel to the Holy Land with hundred men, but with strict orders not to bring anything that could be useful to the Christians' enemies; DN vi, 1864, 204.

33 Hofmann 1957-1958.

34 DN VII, 1869, 215; DS 4384/SDHK 5697.

35 The document is published, with an extensive discussion of the context, in Fritz and Odelman 1992; see also Madurell y Marimón 1966, 486-489, who mentions Petrus of Media Villa bringing twenty-eight falcons to Alexandria, with only five reaching their destination alive.

36 On this theme in relation to Old French literature, see Kinoshita 2006. 


\subsection{Trading with the Sámi}

From the twelfth to the fourteenth centuries, Norwegians were involved in the Crusades against the Muslims. At the same time, the heathen Sámi, or Finnar as they were usually called in Old Norse, were a close neighbour to the Norwegians. Since the Viking Age, chieftains and petty kings in the South had traded with and taxed the Sami. After the Christianization of Norway, the northern Finnmark region was associated with heathendom, and its inhabitants with sorcery. Beginning in the thirteenth century, a growing number of Norwegians settled in Finnmark, but control over the area was challenged by the Russian princes of Novgorod, who were also interested in northern Scandinavia. In response to this, the Norwegian rulers built churches in the region, and in the early fourteenth century erected a fortress in Vardø. ${ }^{37}$

In the middle of the twelfth century, an anonymous chronicler connected to the Archbishopric of Nidaros described the Finns. Above all, he emphasized their religious practices, claiming that "a person will scarcely believe their unendurable impiety and the extent to which they practice heathen devilry in their magic arts". ${ }^{38}$ At the same time, he stated as a matter of fact that Norwegians habitually traded with the heathen Finns. He offers an anecdote: "Once, when Christians who had come to trade had sat down at table with some Finns, their hostess fell forward all of a sudden and expired". 39 This is followed by an account of how two magicians attempted to restore her to life by using a gandr, the "demonic spirit" of a sorcerer who was able to travel long distances, in the shape of a whale, for instance. One of these two sorcerers died while performing the chanting incantations, falling to the ground "negro ut ethiops [black as a negro]". This expression would have been familiar to the learned audience of the text. The meaning of the blackness of the Ethiopian had been discussed since Antiquity. In early Christianity, the distinction of whiteness and darkness was often interpreted in relation to sin. Demons would often be described as Ethiopians with curly hair. ${ }^{40}$ At the same time, Church Fathers, such as Augustine, declared that Ethiopians traced their origin to the same human forms as other people. As rational and mortal beings, they were part of humanity and potential Christians; by converting, they, just like other people, were made white in the light of the Lord. 41

37 Hansen and Olsen 2014, 155-160.

38 Historia Norwegie 2003, 61.

39 Historia Norwegie 2003, 63.

40 Goldenberg 2009.

41 Snowden 1983, 104-105; Courtès 2010, 200-201. 
In some Old Norse sagas, however, there is an ambivalent attitude about the possibility of converting the Sámi. Oddr Snorrason, a Benedictine monk from the Icelandic monastery of Pingeyrar, writing in the late twelfth century, described how the missionary King Olaf Tryggvason received sound advice from a wise Finn who could see into the future. Although helpful to the king, the Finn said that "ek hefi annars konar náttúru [I have a different nature]" and was unable to adopt Christianity or its customs, "Pví at ekki má ek snúast til annarra hluta eða annarrar náttúru en nú em ek [because I cannot convert to other practices or to another form of existence]".42 Later in the saga, King Olaf fails to convert a chieftain from Hálogaland in northern Norway, because he was born as the result of some Finnar using magic to insert an unclean spirit into a woman's womb. This chieftain was, in fact, that very spirit and could not be baptized for the reason that "ek hefi ekki mannz eðli [I have not the nature of a man]". ${ }^{43}$ In this case, the Sámi seem, by their nature, to be immersed in witchcraft, while the Norwegian or Icelandic performers of magic, both before and after their conversion to Christianity, would most often be depicted as having learned magic or specific charms, often from the Finns. ${ }^{44}$ In any case, in the episode of the two magicians in the Historia Norwegie, trade between Norwegians and the Sami is not seen as a problem in and of itself. It is only the practices of the two heathen magicians that are considered demonic and dangerous.

Along with trade, the Sámi are depicted as fishing alongside the Christians. The author relates one such episode in his work: "When the Finns, together with the Christians, had gone about catching by hook a flock of fish such as these heathens had seen in Christian dwellings, they drew almost full traps out of the deeps with their wand, and so loaded the boats to capacity". ${ }^{45}$ Here, the Sámi are more or less doing the same thing as the Norwegians. The historical context for this episode is the increased and lucrative trade in fish exported to the south. Both the Sámi and the Norwegians who were settled further north wanted a piece of this trade, and in this instance the author clearly portrays the Sámi as imitating the Norwegian practice. It is the religious context of the fishing, with the Sámi successfully using sorcery, which denotes the difference between the two groups.

In the fishing episode in Historia Norwegie, the Finns used the wand and were more successful than the Norwegians. Another writer from the late twelfth

42 Oddr Snorrason 2003, 66.

43 Oddr Snorrason 2003, 96.

44 Mitchell 2003.

45 Historia Norwegie 2003, 63. 
century emphasized that Christians should under no circumstances adopt this kind of sorcery. When compiling a collection of Saint Olaf's miracles, Archbishop Eystein Erlendsson of Nidaros (1167-1188) told the story of a remarkable Norwegian catch in northern pagan lands: "For lying in a narrow inlet in the middle of the pagan wastes, three or four weeks distant from Christian lands, and disappointed of their expected catch [...] they humbly besought with plea and with prayer the mercy of God and the intervention of the martyr." 46 Their success attracted the attention of the Sámi (or Lapps as they are called here): "The pagan Lapps who had also gathered there to fish, hearing the vow of the faithful, asked to be admitted as fellows to this plan, but in such a way that their gods should be no less honoured with the fruits of their vow than the blessed Olaf with the offerings of the faithful. But since there is no concord between Christ and Belial, the wretches in their error were spurned". ${ }^{47}$ Archbishop Eystein then described how the Norwegians sent fish to the cathedral in Nidaros to express their gratitude for Saint Olaf's intervention.

This was clearly seen as a remarkable and important miracle, and Archbishop Eystein claimed to have verified it himself. When travelling to the fringe of heathen lands, he had questioned truthful men about what had happened, and they all told him the same story. Whereas the fishing episode in Historia Norwegie presents the Sámi sorcery as particularly effective in procuring a good catch, Archbishop Eystein depicts the worship of the saint as more fruitful. It seems like the Archbishop was concerned about the extremely close relationship between the Norwegians and the Sámi - not the fishing as such, but the fear that it would lead to a mixed worship of saints and heathen gods. Archbishop Eystein emphasized that Christians would receive more help from Saint Olaf, and that the saint's intervention was the result of the unwillingness of the Norwegians to take part in the Lapps' worship. It is not explicitly stated in the account of the miracle, but in the light of the parallel episode in the Historia Norwegie, we could presume that Archbishop Eystein believed that the heathens' sorcery actually was an effective way to catch fish. This made Christian fishermen in the northern pagan lands of central importance in establishing Christianity's distinction from the heathendom and the works of the Devil. Fishing became a battle between "Christ and Belial”, and even if the Christians and heathens fished side by side, the way they worshipped served to introduce Christianity to the heathens and to mount a defence against the trappings of the Devil in these heathen realms. If all the Christian fishermen were to worship Saint Olaf in the same way, they would not only be economically success-

46 Phelpstead and Kunin 2001, 70.

47 Phelpstead and Kunin 2001, 70-71. 
ful, they would also help to Christianize these realms. It was a vision of Crusading while fishing.

These sources suggest that while they perceived the Sámi as a religious Other, the Norwegians also viewed them as a people with a king they could negotiate with. In 1313, Martin, the "king of the Finns", is said to have visited the Norwegian king, Hákon V (1299-1319). ${ }^{48}$ That same year, King Hákon issued a legal amendment concerning the northern part of the kingdom, ${ }^{49}$ offering the Finns privileges if they converted to Christianity. For thirty years after their conversion, they would pay only one third of any fines imposed by royal officials. Hákon $\mathrm{V}$ also admonished both his own officials and the Archbishop of Nidaros' officials to treat the Finns justly and not to exploit them economically. It seems that Martin was some sort of Sámi chieftain - perhaps a Christian (as his name would suggest) - who was negotiating on behalf of his people. ${ }^{50}$

Few sources show active attempts to convert the Sámi during the fourteenth century. One episode in the late 1350 s or the 1360 s indicates that the mission to the Sámi continued to follow in the wake of trade. A certain priest from Hálogaland travelled with merchants by ship to Finnmark. They entered a suitable harbour and were met by numerous Sámi, who had come to trade with them. One day, the priest was saying Mass in a tent, since there were no chapels or churches in the area. The Finns joined the Christians at Holy Mass. Among them was a man who stood by the door of the tent. This man was greatly skilled in witchcraft. He was revered by all of the Finns as their leader, both because of his sorcery and because he could foretell the future. However, when the hostia was raised, the sorcerer fled from the tent. He was later found lying on the ground. He explained to the Norwegians' interpreter that the consecrated host had appeared to him to be a brightly illuminated child covered in blood. The Finn had fainted in terror. This miracle was reported by the priest to Archbishop Olaf of Nidaros, who ordered that it be announced from the choir of the cathedral for all to hear, and that the announcement be accompanied by chiming bells and the chanting of the hymn Te deum. ${ }^{51}$

48 Islandske annaler 1888, 393: "Petta sumar kom Marteinn Finna kongr til Hakonar kongs." His visit to King Hákon V is also mentioned by Hans Lilienskiold, the provincial governor of Finnmark in the late seventeenth century, see Bratrein 2001. In both the kings' sagas and the legendary sagas, we find many references to kings in Finnmark, often mentioned along with their attractive daughters, see Hermann Pálsson 1997, 131-157.

49 Keyser et al. 1849, 106-107.

50 Mundal 2006.

51 This story was first written in Latin at Nidaros, but only the Icelandic translation by the priest Einarr Hafliðason (1307-1393) remains extant, see Kålund 1908, 57-59. 
The narrator expresses doubt about the sorcerer's conversion to Christianity. He attended the Mass with the other Finns, but is referred to as a heathen, while the others are portrayed as believing in his sorcery more than in Christ. In any event, the conversion of the Finns was obviously not the point of this story or the reason it was announced with such veneration in Nidaros. The main message was that the power of Holy Mass was greater than the skills of the northern pagan sorcerers. Norwegian traders who travelled to these areas could expect God's support, and if they performed Christian rituals, the pagans would recognize God's power.

This episode also indicates that Norwegian merchants and priests met people in the North who did not have the negative attitude towards Christianity that Crusaders had grown to expect of the Saracens in the Mediterranean. On the contrary, the Sámi were depicted as attending Mass, even though they considered a sorcerer their leader. It is likely that many of the Sámi had become catechumens, possibly by proclaiming the Symbol of Faith, renouncing the Devil, and being blessed with the sign of the cross (prima signatio). ${ }^{52}$ There are, however, many indications that the Sámi incorporated elements of Christianity and Christian symbolism into their own religion in an adapted form, rather than choosing between Christianity and their traditional beliefs. ${ }^{53}$ This kind of hybrid religion is also reflected in the buildings known as multi-room houses. Archaeological excavations have shown that these sites on the coast of modern Finnmark can be connected to Norwegians, the Sámi, and the Karelians. Of a turf, stone, and wood construction, such houses might have served several functions in a multi-ethnic environment. ${ }^{54}$ For example, they might have allowed for communication and facilitated peaceful trade between people from different cultures. ${ }^{55}$

In the economic and political relations in north Scandinavia, the religious or ethnic differences of the Norwegians and the Sámi seem to have given rise to very little conflict or violence. Most conflict and violence was over taxes and control of trade, and occurred between Norwegians and Karelians, who were acting on behalf of Novgorod. ${ }^{56}$ The accounts of religious conflict provided by the Church of Nidaros focused on trade and fishing, rather than on a military

52 On the various rituals of prima signatio, see Uspenskij 2009; see also Mundal 2006 on the Sámi who traded with Christians having performed 'primsigning' or 'first-signing'.

53 Hansen and Olsen 2014, 313-315.

54 Olsen, Henriksen, and Urbańczyk 2011.

55 Aalto (2010, 173-179) emphasizes the establishment of kaupfriðr (trading peace), to allow for trading between Christians and heathens.

56 Hansen and Olsen 2014, 141-227. 
Crusade led by the Norwegian king. The accounts in question present the activities of the two peoples as so intermingled that distinctions were barely visible. This made it necessary to introduce the issue of religious worship to denote a meaningful difference between them. The conflict between Norwegians and the Sámi had to be transformed into a relationship between Christendom and heathens. In this relationship, Christian ideology would be presented as hegemonic, but the narratives provide a view of numerous instances of peaceful interaction between the two groups, and even cases of Norwegians being tempted to use Sámi "sorcery". This was why the Archbishop of Nidaros felt it was necessary to announce the miracle of the sorcerer who was struck with terror at the sight of the consecrated host during Mass.

\subsection{Concluding remarks}

In the early sixteenth century, the Portuguese humanist Damião de Góis wrote a treatise on the Lapps, entitled the Deploratio Lappiannae gentis. Damião's source for the treatise was the last Catholic archbishop of Sweden, Johannes Magnus (1488-1544). Johannes Magnus had told Damião that he wished to convert the Lapps to Catholicism, but as the Swedish king had converted to Lutheranism this was impossible. He feared that King Gustav Vasa of Sweden would exploit the Lapps economically, rather than convert them. Damião himself bemoaned the fact that the Lapps had not yet been Christianized, blaming this on the greed of kings and merchants who preferred that they remain heathens, so they could be more heavily taxed. 57

In the period of the twelfth through the fourteenth centuries, however, there would have been no perceived contradiction between Christian preaching, colonization and trade or between missionaries and merchants. It is true that King Hákon V’s 1313 legal amendment concerning the Sámi included economic privileges for those Sámi who converted. These trading privileges were seen as promoting Christendom in the North. In 1358, King Erik Magnusson of Sweden confirmed the existing trading privileges in the northern realms, in part because they encouraged the growth of Christianity (christna troes föröckning). ${ }^{58}$ From the Archbishopric of Nidaros' perspective, the central issue was not the converting of individual heathens in the North, but rather building churches and performing Mass for the Norwegian traders and settlers in the region. The miracle stories reflect the close interaction of Norwegians and the

57 Earle 2006, 358.

58 DS 5959/SDHK 7420. 
Sámi, and were meant to ensure Christians that they received no less support from Saint Olaf than the heathens did from their sorcerers. Given that they fished side by side and ate together, it was essential to remind the Norwegian merchants and settlers that the heathens threatened their salvation.

Although, in Finnmark, the Norwegians were not fighting to defend or recover a Holy Land from a group that refused to acknowledge Christianity, it nonetheless seems that they drew upon lessons learned from trade between Christians and Muslims in the Mediterranean. For merchants from a city like Genoa, combining Crusading and trade would have been the norm. In a similar vein, the Scandinavian Crusaders of the early 1150s would fight fierce battles with the blámenn one day and trade with Serkir/Saracens the next day. The first group played the role of monstrous and demonic forces in the narratives, while the merchants and rulers were presented in stories highlighting exotic luxury and chivalrous values. Depending on context, the Saracens might even be depicted as chivalrous warriors worthy of the Christians' respect. In what may be called aristocratic discourse, the parameters were not those of religious Otherness, but of the shared values of some Christian and heathen warriors.

While in the case of the Muslims, the violence against the heathen blámenn served as a reminder of the distinction between Us and the Other, in Finnmark, the Sámi often accepted baptism and attended Mass, making the lines blurry for Norwegian traders and priests. The dominant discourse about the Finnar in the sagas addresses their attachment to sorcery, to controlling the weather, and to shapeshifting. Clerical authors in Nidaros invoked such images to transform the peaceful encounters between Norwegians and the Sámi into a religious battle between Christianity and heathendom. In relation to trade, these images were used to highlight the differences between the groups. However, traders also had access to more positive images and narratives that legitimized relations with both Muslims and the Sámi.

\section{Bibliography}

\section{Primary sources}

Árna saga biskups. In Biskupa sögur. Vol. 3. Ed. Guðrún Ása Grímsdóttir. Reykjavík: Hið íslenska fornritafélag, 1999. 3-207.

Bird, Jessalynn, Edward Peters, and James M. Powell (Eds.). Crusade and Christendom: Annotated Documents in Translation from Innocent III to the Fall of Jerusalem, 1187-1291. Philadelphia: University of Pennsylvania Press, 2013.

Birkeland, Harris (Ed. and trans.). Nordens historie i middelalderen etter arabiske kilder. Oslo: Det Norske Videnskaps-Akademiet, 1954. 
DN = Diplomatarium Norvegicum. 23 vols. Christiania/Oslo, 1846-2011.

DS = Diplomatarium Suecanum. 11 vols. Stockholm, 1829-2011.

Earle, Tom. “Damião de Góis, Deploratio Lapiannae gentis: Text and Translation.” Humanitas 58 (2006): 347-367.

En tale mot biskopene. Ed. Anne Holtsmark. Oslo: Det Norske Videnskaps-Akademi i Oslo, 1931.

Hákonar saga Hákonarsonar: Icelandic Sagas and Other Historical Documents Relating to the Settlements and Descents of the Northmen on the British Isles. Vol. 2. Hákonar Saga and a Fragment of Magnus Saga with Appendices. Ed. Guðbrandur Vigfússon. London: Stationery Office, 1887.

Historia Norwegie. Eds. Lars Boje Mortensen and Inger Ekrem. Trans. Peter Fisher. Copenhagen: Museum Tusculanum, 2003.

Islandske Annaler indtil 1578. Ed. Gustav Storm. Christiania, 1888.

Keyser, Rudolf, et al. (Eds.). Norges Gamle Love indtil 1387. Vol. 3. Kristiania/Oslo, 1849. Kålund, Kr. Alfræði íslenzk. Vol. 1. Cod. Mbr. AM. 194, 8vo. København: Møllers, 1908. Konungs skuggsiá. Ed. Ludvig Holm-Olsen. $2^{\text {nd }}$ edn. Oslo: Norsk historisk kjeldeskriftinstitutt, 1983.

Lopez, Robert S., and Irving W. Raymond. Medieval Trade in the Mediterranean World: Illustrative Documents with Introductions and Notes. New York: Columbia University Press, 1955.

Oddr Snorrason. The Saga of Olaf Tryggvason. Trans. Theodore M. Andersson. Ithaca: Cornell University Press, 2003.

Orkneyinga saga. Ed. Finnbogi Guðmundsson. Reykjavík: Hið íslenska fornritafélag, 1965. Phelpstead, Carl (Ed.), and Devra Kunin (Trans.). A History of Norway and The Passion and Miracles of the Blessed Óláfr. London: Viking Society, 2001.

SDHK = Svenskt diplomatariums huvudkartotek över medeltidsbreven. Stockholm: Riksarkivet, 2003. < riksarkivet.se/sdhk >.

\section{Literature}

Aalto, Sirpa. Categorizing Otherness in the Kings' Sagas. Joensuu: University of Eastern Finland, 2010.

Bandlien, Bjørn. "Old Norse Images of Muslims." Fighting for the Faith and Images of the Other. Eds. Janus Møller Jensen, Kurt Villads Jensen, and Carsten Selch Jensen. Forthcoming.

Bandlien, Bjørn, and Gunnar W. Knutsen. "Kjetterinkvisitorer i Norge." Historisk tidsskrift 87 (2008): 433-450.

Bratrein, Håvard Dahl. “Finnekongen Martin og rikskongen Håkon den femte.” Håløygminne 21 (2001): 1-10.

Brunschvig, Robert. La Berbérie Orientale sous les Hafsides: Des Origines a la fin du XVe siècle. Vol. 1. Paris: Adrien-Maisonneuve, 1940.

Cheyette, Fredric L. Ermengard of Narbonne and the World of the Troubadours. Ithaca: Cornell University Press, 2001.

Courtès, Jean Marie. “The Theme of 'Ethiopia' and 'Ethiopians' in Patristic Literature.” The Image of the Black in Western Art. Vol. 2. From the Early Christian Era to the "Age of Discovery". 1. From the Demonic Threat to the Incarnation of Sainthood. Eds. David 
Bindman and Henry Louis Gates. New edn. Cambridge, Mass: Belknap Press of Harvard University Press, 2010. 199-214.

Durkheim, Émile. The Division of Labour in Society. New York: The Free Press, 1964 [1933].

Fritz, Birgitta, and Eva Odelman. "Svensk falkexport till Egypten på medeltiden: Studier kring en affärshandling från 1345 i Barcelona.” Rättshistoriska studier 18 (1992): 64-94.

Goldenberg, David. "Racism, Color Symbolism, and Color Prejudice." The Origins of Racism in the West. Eds. Miriam Eliav-Feldon, Benjamin Isaac, and Joseph Ziegler. Cambridge: Cambridge University Press, 2009. 88-108.

Hansen, Lars Ivar, and Bjørnar Olsen. Hunters in Transition: An Outline of Early Sámi History. Leiden: Brill, 2014.

Hermann Pálsson. Úr landnorðri: Samar og ystu rætur íslenskrar menningar. Reykjavík: Bókmenntafræðistofnun Háskóla Íslands, 1997.

Hofmann, Gisela. "Falkenjagt und Falkenhandel in den nordischen Ländern während des Mittelalters.” Zeitschrift für deutsches Altertum und deutsche Literatur 88 (1957-1958): 115-149.

Jackson, Peter. The Seventh Crusade, 1244-1254: Sources and Documents. Aldershot: Ashgate, 2009.

Jacoby, David. "The Supply of War Materials to Egypt in the Crusader Period." Jerusalem Studies in Arabic and Islam 25 (2001): 102-132.

Kinoshita, Sharon. Medieval Boundaries: Rethinking Difference in Old French Literature. Philadelphia: University of Pennsylvania Press, 2006.

Madurell y Marimón, Jose M. “Contabilidad de una compañía mercantil trecentista barcelonesa (1334-1342).” Anuario de historia de derecho español 36 (1966): 457-546.

Menache, Sophia. "Papal Attempts at a Commercial Boycott of the Muslims in the Crusader Period." Journal of Ecclesiastical History 63.2 (2012): 236-259.

Messier, Ronald. "The Christian Community of Tunis at the Time of St. Louis' Crusade, AD 1270." Meeting of Two Worlds: Cultural Exchange between East and West during the Period of Crusades. Ed. Vladimir Goss. Kalamazoo: Medieval Institute, 1986. 241-255.

Meyerson, Mark D. The Muslims of Valencia in the Age of Fernando and Isabel. Oakland: The University of California Press, 2003.

Mitchell, Stephen. "Magic as Acquired Art and the Ethnographic Value of the Sagas." Old Norse Myths, Literature and Society. Ed. Margaret Clunies Ross. Odense: University Press of Southern Denmark, 2003. 132-152.

Moore, Robert Ian. The Formation of a Persecuting Society: Authority and Deviance in Western Europe, 950-1250. $2^{\text {nd }}$ edn. Malden, Mass.: Blackwell, 2007.

Mundal, Else. "The Perception of the Saamis and their Religion in Old Norse Sources." Shamanism and Northern Ecology. Ed. Juha Pentikäinen. Berlin: De Gruyter, 1996. 97116.

Mundal, Else. “Kong Håkon Magnussons rettarbot for Hålogaland av 1313 og andre kjelder til kristninga av samane i mellomalderen.” Sápmi Y1K: Livet i samernas bosättningsområde för ett tusen år sedan. Eds. Andrea Amft and Mikael Svonni. Umeå: Sámi dutkan, 2006. 97-114.

Nirenberg, David. Communities of Violence: Persecution of Minorities in the Middle Ages. Princeton: Princeton University Press, 1996.

Olsen, Bjørnar, Jørn E. Henriksen, and Przemystaw Urbańczyk. “Interpreting Multi-Room Houses: Origin, Function and Cultural Networks.” Hybrid Spaces: Medieval Finnmark and the Archaeology of Multi-Room Houses. Eds. Bjørnar Olsen, Przemystaw Urbańczyk, and Colin Amundsen. Oslo: Novus, 2011. 371-86. 
Riant, Paul. Expéditions et pèlerinages des Scandinaves en Terre Sainte au temps des croisades. Paris: A. Lainé et J. Havard, 1865.

Schaube, Adolf. Handelsgeschichte der Romanischen Völker des Mittelmeergebiets bis zum Ende der Kreuzzüge. München: Oldenbourg, 1906.

Skånland, Vegard. "Calor Fidei." Symbolae Osloenses 32 (1956): 86-104.

Snowden, Frank M. Before Color Prejudice: The Ancient View of Blacks. Cambridge, MA: Harvard University Press, 1983.

Sverrir Jakobsson. “Íslam og andstæður í íslensku miðaldasamfélagi.” Saga 50.2 (2012): 1133.

Tolan, John. Saracens: Islam in the medieval European Imagination. New York: Columbia University Press, 2002.

Uspenskij, Fjodor. "The Baptism of Bones and prima signatio in Medieval Scandinavia and Rus'." Between Paganism and Chrsitianity in the North. Eds. Leszek Stupecki and Jakub Morawiec. Rzeszów: Wydawnictwo Uniwersytetu Rzeszowskiego, 2009. 9-22. 